\title{
Structural Domains Involved in the Regulation of Transmitter Release by Synapsins
}

\author{
Sabine Hilfiker, ${ }^{1,3}$ Fabio Benfenati, ${ }^{1,2}$ Frédéric Doussau, ${ }^{3,4}$ Angus C. Nairn, ${ }^{1}$ Andrew J. Czernik, ${ }^{1}$ George J. Augustine, ${ }^{3,4}$ \\ and Paul Greengard ${ }^{1}$ \\ ${ }^{1}$ Laboratory of Molecular and Cellular Neuroscience, The Rockefeller University, New York, New York 10021, ${ }^{2}$ Department of Experimental Medicine, \\ Section of Human Physiology, University of Genova, 3-16132 Genova, Italy, ${ }^{3}$ Marine Biological Laboratory, Woods Hole, Massachusetts 02543, and \\ ${ }^{4}$ Department of Neurobiology, Duke University Medical Center, Durham, North Carolina 27710
}

Synapsins are a family of neuron-specific phosphoproteins that regulate neurotransmitter release by associating with synaptic vesicles. Synapsins consist of a series of conserved and variable structural domains of unknown function. We performed a systematic structurefunction analysis of the various domains of synapsin by assessing the actions of synapsin fragments on neurotransmitter release, presynaptic ultrastructure, and the biochemical interactions of synapsin. Injecting a peptide derived from domain A into the squid giant presynaptic terminal inhibited neurotransmitter release in a phosphorylation-dependent manner. This peptide had no effect on vesicle pool size, synaptic depression, or transmitter release kinetics. In contrast, a peptide fragment from domain $\mathrm{C}$ reduced the number of synaptic vesicles in the periphery of the active zone and increased the rate and extent of synaptic depression. This peptide also slowed the kinetics of neurotransmitter release without affecting the number of docked vesicles. The domain $\mathrm{C}$ peptide, as well as another peptide from domain $\mathrm{E}$ that is known to have identical effects on vesicle pool size and release kinetics, both specifically interfered with the binding of synapsins to actin but not with the binding of synapsins to synaptic vesicles. This suggests that both peptides interfere with release by preventing interactions of synapsins with actin. Thus, interactions of domains $\mathrm{C}$ and $\mathrm{E}$ with the actin cytoskeleton may allow synapsins to perform two roles in regulating release, whereas domain A has an actin-independent function that regulates transmitter release in a phosphorylation-sensitive manner.

Key words: synapsin; release; regulation; neurotransmitter; actin; cytoskeleton; depression

\section{Introduction}

Synapsins are a family of presynaptic phosphoproteins that associate with synaptic vesicles (SVs) (Huttner et al., 1983; De Camilli et al., 1990; Greengard et al., 1993; Hilfiker et al., 1999). Synapsins are expressed in vertebrate and invertebrate nervous systems, with a single gene found in invertebrates (Klagges et al., 1996; Hilfiker et al., 1998; Kao et al., 1999; Humeau et al., 2001) and three genes (synapsins I, II, and III) found in mammals (De Camilli et al., 1990; Hosaka and Südhof, 1998b; Kao et al., 1998). The primary structure of synapsins consists of multiple common and unique regions (Südhof et al., 1989; Kao et al., 1999). These

\footnotetext{
Received 0ct. 14, 2004; revised Jan. 20, 2005; accepted Jan. 21, 2005.

This work was supported by grants from The Fisher Center for Alzheimer's Disease Research (P.G., F.B.), National Institutes of Health Grants NS-21624 (G.J.A.) and MH39327 (P.G.), the Italian Ministry of Education (F.B.), Consorzio Italiano Biotecnologie (F.B.), and a Ramon y Cajal fellowship (S.H.). We thank Sheila Roberts for electron microscopy analysis and Drs. Franco Onofri and Silvia Giovedi for help with some experiments.

Correspondence should be addressed to Dr. Sabine Hilfiker, Consejo Superior de Investigaciones Cientificas, Institute of Parasitology and Biomedicine "López-Neyra," Avenida De Conocimiento sin numero, 18100 Armilla, Granada, Spain. E-mail: sabine.hilfiker@ipb.csic.es.

F. Doussau's present address: Neurotransmission et Sécrétion Neuroendocrine, Centre National de la Recherche Scientifique, Unité Propre de Recherche 2356, 5 rue Blaise Pascal, 67084 Strasbourg, Cedex, France.

A. J. Czernik's present address: PhosphoSolutions Inc., 12635 East Montview Boulevard, \#213, Aurora, C0 80012-3785.

DOI:10.1523/JNEUROSCI.4278-04.2005

Copyright $\odot 2005$ Society for Neuroscience $\quad$ 0270-6474/05/252658-12\$15.00/0
}

are thought to represent functional domains, although their specific functions are not yet clear.

Several lines of evidence indicate that synapsins regulate the supply of synaptic vesicles available for exocytosis. Perturbation of synapsin function in a variety of experimental systems increases synaptic depression, indicating that synapsins are required to sustain neurotransmitter release during high levels of neuronal activity (Li et al., 1995; Pieribone et al., 1995; Rosahl et al., 1995; Takei et al., 1995; Hilfiker et al., 1998; Chi et al., 2001; Humeau et al., 2001; Gitler et al., 2004b). These perturbations also decrease the number of vesicles in the periphery of the active zone, suggesting that synapsins participate in transmitter release by regulating a reserve pool of synaptic vesicles. Synapsins have also been implicated in other forms of short-term plasticity, such as posttetanic potentiation (Rosahl et al., 1993, 1995; Humeau et al., 2001), and in modulating a post-docking step of the release process (Hilfiker et al., 1998; Humeau et al., 2001).

In vitro, synapsins exhibit a number of biochemical activities. They bind, in a phosphorylation-dependent manner, to lipid and protein components of synaptic vesicles (Schiebler et al., 1986; Benfenati et al., 1989a,b). This may allow synapsins to associate with synaptic vesicles. Synapsins also bind to various cytoskeletal proteins, including actin, spectrin, and microtubules (Baines and Bennett, 1985, 1986; Bähler and Greengard, 1987; Petrucci and Morrow, 1987; Benfenati et al., 1992a; Hurley et al., 2004). These 
properties may allow synapsins to keep vesicles in the reserve pool by reversibly cross-linking vesicles to each other and/or to the presynaptic cytoskeleton. In addition, synapsins bind ATP (Hosaka and Südhof, 1998a) and are structurally similar to a group of ATP-using enzymes (Esser et al., 1998; Brautigam et al., 2004), suggesting that synapsins may have an enzymatic function.

In this paper, we correlated the structural, physiological, and biochemical properties of synapsins by defining the functions of individual domains of synapsins. Our data support the idea that synapsins are multifunctional proteins and that individual domains confer specific functions to synapsins. Domains $\mathrm{C}$ and $\mathrm{E}$ regulate the availability of synaptic vesicles for release by binding to a presynaptic actin scaffold and thereby maintaining a vesicle pool in the periphery of the plasma membrane, whereas domain A has a different function that regulates neurotransmitter release in a phosphorylation-dependent manner.

\section{Materials and Methods}

Peptides. Peptides were synthesized either by the Keck Foundation Biotechnology Resource Laboratory at Yale University (New Haven, CT), by the Rockefeller University Protein/DNA Technology Center (New York, $\mathrm{NY}$ ), or by Research Genetics/Invitrogen (Huntsville, AL). In all cases, peptides were purified ( $>95 \%$ pure) by reversed-phase HPLC, and their identity was confirmed by mass spectroscopy. Peptides were resuspended in peptide injection buffer (in mм: $200 \mathrm{KCl}, 100$ taurine, 200 $\mathrm{K}$-isethionate, and $50 \mathrm{~K}$-HEPES, $\mathrm{pH}$ 7.4) that was designed to mimic squid axoplasm while maintaining proper secondary structure of the peptides. The final concentration of peptide in the injection solution ranged from 2 to $40 \mathrm{~mm}$; if necessary, the $\mathrm{pH}$ was adjusted to 7.4. All peptides were subjected to sequence similarity searches using the National Center for Biotechnology Information BLAST (basic local alignment search tool) program (www.ncbi.nlm.nih.gov) to ensure that the peptides had no significant homology with the sequences of other proteins. In addition, secondary structure predictions (http: //www.predictprotein.org) were performed for all peptides. In cases in which a prediction indicated a high probability for a given peptide to form a distinct secondary structure, control scrambled peptides were designed to retain this feature of predicted secondary structure.

Physiological measurements. Electrical measurements and microinjections were performed on isolated stellate ganglia of Loligo pealei, as described previously (Bommert et al., 1993; Hilfiker et al., 1998). In brief, ganglia were superfused with oxygenated physiological saline $\left(10-15^{\circ} \mathrm{C}\right)$ containing the following (in $\mathrm{mM}$ ): $466 \mathrm{NaCl}, 54 \mathrm{MgCl}_{2}, 11 \mathrm{CaCl}_{2}, 10 \mathrm{KCl}$, $3 \mathrm{NaHCO}_{3}$, and 10 HEPES, pH 7.2. Electrodes filled with $3 \mathrm{M} \mathrm{KCl}$ were inserted into the presynaptic and postsynaptic axons. Unless otherwise noted, action potentials were evoked every $30 \mathrm{~s}(0.033 \mathrm{~Hz})$ by depolarizing the presynaptic axon with a current pulse $(0.7-1.9 \mathrm{~mA}, 0.5 \mathrm{~ms}$ duration). Transmitter release was measured by recording EPSPs elicited by presynaptic action potentials and measuring the rate of rise of the EPSPs at a time point before the responses reached action potential threshold. A third microelectrode was used to microinject reagents and record the presynaptic action potential. The microinjection electrode was connected to a Picospritzer injector (General Valve, Fairfield, NJ) that applied pulses of positive pressure (10-90 ms; $10-100 \mathrm{psi} ; \mathrm{N}_{2}$ gas) and contained peptides dissolved to the indicated concentrations in peptide injection buffer. Fluorescein dextran (polymer size of $3 \mathrm{kDa}, 0.1 \mathrm{~mm}$; Molecular Probes, Eugene, OR) was coinjected to estimate the amount of peptide that had been injected. The resulting fluorescence was imaged with a Zeiss (Oberkochen, Germany) Axioskop microscope (10× magnification) and detected with a Cohu (San Diego, CA) silicon-intensified target camera. Depression was elicited by a train of stimuli $(5 \mathrm{~s}, 50 \mathrm{~Hz})$, and the time course of depression was estimated from doubleexponential fits to the time-dependent decay of EPSP slopes during the train. The time constants $(\tau)$ shown are those of the faster and larger exponential term. Synaptic depression was measured while lowering external calcium concentration from 11 to $2.2-3.7 \mathrm{~mm}$. For voltage-clamp recordings, the current-passing and voltage-measuring electrodes con- tained $7 \mathrm{M} \mathrm{CsCl}$ and $3 \mathrm{M} \mathrm{KCl}$, respectively (Augustine et al., 1985). Signals were recorded with an Axoclamp-2A amplifier (Axon Instruments, Union City, CA). Data were filtered at $3-10 \mathrm{kHz}$, digitized at $33 \mathrm{kHz}$, and analyzed using software written in Axobasic (Axon Instruments).

Electron microscopy. Fixation and processing of squid tissue was conducted as described previously (Sanchez et al., 1990). Briefly, peptides were microinjected, and their physiological effects were simultaneously monitored by eliciting presynaptic action potentials every $30 \mathrm{~s}$. Terminals injected with control (scrambled) or active peptides (inhibition of transmitter release $>85 \%$ ) were fixed and processed together. For each condition, two terminals were analyzed, and the data were pooled. All terminals were sectioned, at $75 \mu \mathrm{m}$ intervals, along their length, and sections were examined with a JEM-1200 ExII (Joel, Peabody, MA) electron microscope. Images of all active zones encountered were digitized and analyzed using Image- 1 software (Universal Imaging Corporation, Philadelphia, PA). Because active zones typically are spaced $\sim 1 \mu \mathrm{m}$ apart, only synaptic vesicles within $500 \mathrm{~nm}$ of the active zone were measured to ensure that vesicles were only counted once. Morphometric analyses were done blind to condition, with experimental and control micrographs analyzed in intermixed groups of unknown treatment.

Phosphorylation assays. Synapsin I was purified from bovine brain as described previously (Schiebler et al., 1986; Bähler and Greengard, 1987) and used as a control to test the activity of all kinases studied. The catalytic subunit of protein kinase A (PKA) was purified from bovine heart as described previously (Kaczmarek et al., 1980). Recombinant calcium/ calmodulin-dependent protein kinase I (CaMKI) was expressed in bacteria and purified as described previously (Picciotto et al., 1993). Peptide phosphorylation assays were performed as described previously (Hemmings et al., 1989; Picciotto et al., 1992).

For kinetic analyses, phosphorylation assays were performed with peptide concentrations that varied from 2 to $500 \mu \mathrm{M}$. The total amount of PKA catalytic subunit and CaMKI per reaction was 50 and $25 \mathrm{ng}$, respectively. The incorporation of ${ }^{32} \mathrm{P}$ was linear with these concentrations of peptides and kinases. The $K_{\mathrm{m}}$ and $k_{\text {cat }}$ values were calculated from linear regression analysis of Lineweaver-Burk transformations (1/cpm vs $1 /$ [peptide]), describing the initial rates of phosphorylation as a function of substrate concentration. Data represent means of eight (for PKA) or four (for CaMKI) independent experiments, done in duplicate. The effects of switched squid domain A peptide (switched s-pepA) (10-500 $\mu \mathrm{M}$ final concentration) or of PKI-amide (Walsh inhibitor peptide) [TTYADFIASGRTGRRNAIHD (Walsh et al., 1971; Walsh and Glass, 1991); 5 $\mathrm{nM}$ to $50 \mu \mathrm{M}$ final concentration] on the phosphorylation of s-pepA were assessed under initial rate conditions as described above, and experiments were repeated three times in duplicate.

Synaptic vesicle binding assays. Subcellular fractionation of rat forebrain from homogenate to highly purified SVs was performed through the step of controlled-pore glass chromatography as described previously (Huttner et al., 1983). Purified synaptic vesicles containing endogenous synapsins (untreated SVs) were quantitatively depleted of synapsin I by exposure to mild salt treatment (synapsin-depleted SVs) and reassociated in vitro with purified synapsin I (rebound SVs) as described previously (Schiebler et al., 1986). The complete removal of endogenous synapsins from SVs during salt treatment (Huttner et al., 1983) was routinely verified by immunoblotting. The binding of synapsin I to synapsin-depleted SVs was measured using a high-speed sedimentation assay (Benfenati et al., 1989b). The recovery of SVs, used to correct the amounts of bound synapsin I, was determined by immunoblotting of parallel samples using anti-synaptophysin antibodies. Nonspecific binding was determined as measured by the amount of synapsin I in the pellet in the absence of synaptic vesicles.

Actin binding, bundling, and polymerization assays. Globular actin (Gactin) $(5 \mu \mathrm{M})$, purified as described previously (Benfenati et al., 1992a), was polymerized for $1 \mathrm{~h}$ at room temperature by the addition of $90 \mathrm{mM}$ $\mathrm{KCl} / 1 \mathrm{~mm} \mathrm{MgCl}$ and incubated at $25^{\circ} \mathrm{C}$ for $1 \mathrm{~h}$ with or without $0.5 \mu \mathrm{M}$ synapsin I, and in the presence or absence of either pepA, pepC5, pepE or scrambled versions thereof $(0.1-5 \mathrm{~mm})$. Identical samples were centrifuged either at low speed $(10,000 \times g$ for $10 \mathrm{~min})$ for recovery of actin bundles or subjected to high-speed centrifugation in a Beckman Instruments (Fullerton, CA) TLA-100 rotor $(400,000 \times g$ for $30 \mathrm{~min})$ for 
Table 1. Effects of synapsin peptides on synaptic transmission

\begin{tabular}{|c|c|c|c|c|}
\hline Peptide & $\begin{array}{l}\text { Concentration } \\
\text { (mM) }\end{array}$ & $\begin{array}{l}\text { Number of } \\
\text { injections }\end{array}$ & $\begin{array}{l}\text { Amplitude } \\
\text { inhibition (\%) }\end{array}$ & $\begin{array}{l}\text { Full inhibition } \\
(>95 \%)\end{array}$ \\
\hline s-pepA & 20 & 10 & $75 \pm 6$ & Yes \\
\hline s-pepB & 20 & 3 & $14 \pm 11$ & No \\
\hline rl-pepC1 & n.s. & & & \\
\hline s-CaM1 & 10 & 3 & $83 \pm 13$ & Yes \\
\hline rl-pepC3 & n.s. & & & \\
\hline rl-pepC4 & 3 & 4 & 0 & No \\
\hline rl-pepC5 & n.s. & & & \\
\hline rl-pepC11 & n.s. & & & \\
\hline s-pepC1 & 20 & 4 & $13 \pm 1$ & No \\
\hline s-pepC2 & 10 & 6 & $33 \pm 13$ & No \\
\hline s-TID3N & 10 & 7 & $-19 \pm 2$ & n.a. \\
\hline s-pepC3 & n.s. & & & \\
\hline s-pepC4 & n.s. & & & \\
\hline s-CaM2 & 10 & 3 & $75 \pm 11$ & No \\
\hline s-pepC5 & 10 & 14 & $80 \pm 5$ & Yes \\
\hline rl-pepC12 & n.s. & & & \\
\hline s-pepC6 & n.s. & & & \\
\hline rl-pepC13 & 3 & 3 & 0 & No \\
\hline s-pepV1 & 40 & 3 & 0 & No \\
\hline s-pepV2 & 20 & 3 & 0 & No \\
\hline s-pepV3 & 20 & 1 & 0 & No \\
\hline Short s-pepE & 2 & 5 & $80 \pm 6$ & Yes \\
\hline
\end{tabular}

Peptides correspond to the sequences indicated in Figure 1. They were dissolved to the indicated concentrations in peptide injection buffer. n.S., Not soluble; n.a., not applicable. EPSPs were measured before and at the peak of inhibition of the indicated peptides. Data are means \pm SEM. Peptides were scored as being able to fully inhibit neurotransmitter release if they could decrease EPSPs by $>95 \%$ in at least two individual experiments. s-, Peptides derived from squid synapsin sequences; $r$ l-, peptides derived from rat synapsin I sequences.

recovery of total filamentous actin (F-actin) (Bähler and Greengard, 1987). The actin pellets and supernatant fractions were solubilized in Laemmli's sample buffer and subjected to SDS-PAGE (Laemmli, 1970). The amounts of actin in the various fractions were detected by Coomassie blue staining, whereas the amounts of synapsin I bound to actin, or free in the supernatant, were determined by either protein staining of the gels or immunoblotting. The relationship between peptide concentration and degree of inhibition of the interaction of synapsin with F-actin by various peptides was determined by quantifying the amounts of pelleted synapsin I by normalizing relative to the amounts of pelleted F-actin. Quantitative analysis of Coomassie blue-stained gels or immunoblots was performed by laser scanning densitometry (Ultroscan XL; LKB-Produkter, Bromma, Sweden) by interpolation of the density values into a suitable standard curve.

The polymerization of actin in the absence of $\mathrm{K}^{+} / \mathrm{Mg}^{2+}$ was monitored by recording the enhancement of pyrenyl-actin fluorescence in a PerkinElmer (Wellesley, MA) LS50 spectrophotometer as described previously (Fesce et al., 1992; Valtorta et al., 1992).

\section{Results}

\section{Identification of functional domains of synapsins}

To identify functionally important regions of synapsins, we designed a series of peptides covering almost the entire sequence of squid synapsins (supplemental Fig. 1, available at www. jneurosci.org as supplemental material). When the homology between squid and rat synapsins was high, we also used previously synthesized peptides derived from the sequences of rat synapsins. Some of the peptides derived from hydrophobic regions within the central, conserved domain $\mathrm{C}$ of synapsins were insoluble in injection buffer and could not be considered further. The remaining peptides were dissolved in injection buffer at the highest possible concentration and then microinjected into the giant presynaptic terminal of squid. The amount of peptide injected varied from experiment to experiment, depending on the ability of the microinjection pipette to deliver peptide. For each peptide, we determined the mean degree of inhibition produced, across all
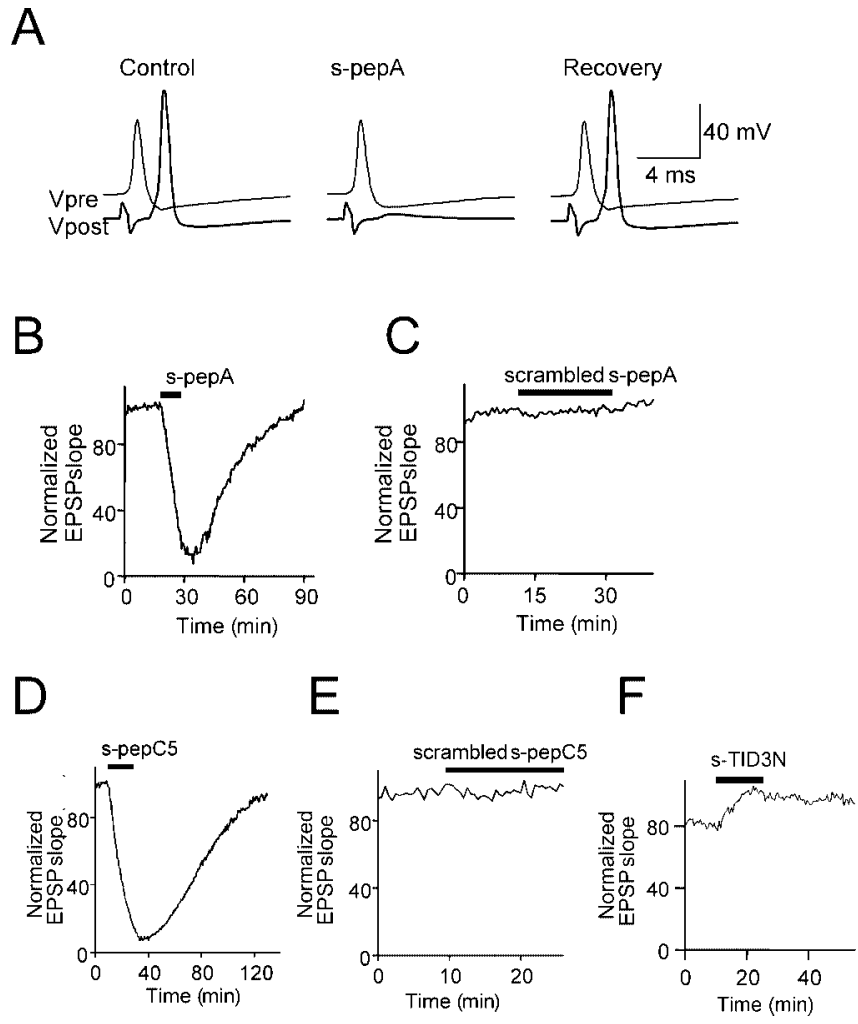

Figure 1. s-pepA and s-pepC5 inhibit neurotransmitter release. $A$, Examples of presynaptic and postsynaptic potentials recorded before (Control), during (s-pepA), and $1 \mathrm{~h}$ after (Recovery) injection of s-pepA. B, Injection of s-pepA (solid bar) reversibly inhibited transmitter release. $\boldsymbol{C}$, Scrambled s-pepA had no effect on transmission. $\boldsymbol{D}$, Injection of s-pepC5 (solid bar) reversibly inhibited neurotransmitter release. $\boldsymbol{E}$, Scrambled s-pep $\boldsymbol{C 5}$ had no effect on transmission. $\boldsymbol{F}, \mathrm{A}$ peptide derived from a region reported to interact with the hydrophobic core of the phospholipid bilayer (s-TID3N) enhanced synaptic transmission.

experiments, whether or not saturating concentrations of peptide were injected. This parameter provides a means of distinguishing active from inactive peptides and is indicated as Amplitude inhibition in Table 1. In addition, for those peptides that were found to be active, we further determined whether a saturating concentration of peptide was able to completely inhibit synaptic transmission (Table 1, Full inhibition).

Several peptides were found to have dramatic effects on neurotransmitter release. A peptide derived from the evolutionarily conserved domain A of squid synapsins caused a pronounced and reversible reduction in the amplitude and rate of rise of EPSPs evoked by presynaptic action potentials (Fig. $1 A$ ). In the example shown in Figure $1 A$, the inhibition of transmitter release induced by this peptide, termed s-pepA, was sufficient to reduce EPSPs below the threshold for evoking an action potential (middle). Synaptic transmission could be completely abolished by injection of a sufficient amount of s-pepA, and the inhibition of transmission was reversed after ceasing peptide injection (Fig. $1 \mathrm{~A}$, right, $B$ ). This recovery presumably was attributable to diffusion of the peptide out of the presynaptic terminal and into the adjacent presynaptic axon. This indicates that the inhibition was attributable to the action of the peptide rather than the injection procedure per se. A scrambled control peptide (scrambled s-pepA), possessing an amino acid composition identical to that of s-pepA and similar predicted secondary structure but with a randomized primary sequence, had no effect on transmitter release (Fig. $1 C$, Table 2). This indicates that the inhibition of transmitter release 
Table 2. Structural requirements for peptide inhibition of synaptic transmission

\begin{tabular}{|c|c|c|c|c|}
\hline Peptide & Sequence & Concentration (mм) & $\begin{array}{l}\text { Number of } \\
\text { injections }\end{array}$ & $\begin{array}{l}\text { Amplitude } \\
\text { inhibition (\%) }\end{array}$ \\
\hline s-pepA & VGFLKRRFSSGDLQGELRDAQE & 20 & 10 & $75 \pm 6$ \\
\hline Phospho-s-pepA & VGFLKRRFSSGDLQGELRDAQE & 20 & 4 & 0 \\
\hline Switched s-pepA & VGFLKRRFGDSSLQGELRDAQE & 20 & 4 & $57 \pm 12$ \\
\hline Short s-pepA & FLKRRFSSSGDL & 20 & 3 & $66 \pm 17$ \\
\hline Short switched s-pepA & FLKRRFGDSSL & 20 & 2 & $83 \pm 10$ \\
\hline Scrambled s-pepA & VLERFRDQGSGSQLGDFARKLE & 20 & 3 & 0 \\
\hline s-CaM1 & TDWSKYFRGKKIFGDWDLRVE-amide & 10 & 3 & $83 \pm 13$ \\
\hline s-pepC2 & PKFPVVVKIGHAHSGMGKVKVD-amide & 10 & 6 & $33 \pm 13$ \\
\hline s-pepC5 & AFLRKSISGNWKANTGSAMLEQI-amide & 10 & 14 & $80 \pm 5$ \\
\hline Scrambled s-pepC5 & $\begin{array}{l}\text { SKWAEAINLSGLFTMKGINQRAS-amide } \\
*\end{array}$ & 10 & 6 & $7 \pm 5$ \\
\hline Mutant s-pepC5 & AFLRKSISGNWQANTGSAMLEQI-amide & 10 & 3 & $14 \pm 8$ \\
\hline s-CaM2 & VQKIGNNYKAFLRKSISG-amide & 10 & 3 & $75 \pm 11$ \\
\hline s-TID3N & GKVKVDHHHAFQDIASVVAVTKS-amide & 10 & 7 & $-19 \pm 2$ \\
\hline
\end{tabular}

Peptides were dissolved to the indicated concentrations in peptide injection buffer. EPSPs were measured before and at the peak of inhibition of the indicated peptides. Data are means \pm SEM. The consensus sequences for phosphorylation are underlined. The phosphorylated residue in phospho-s-pepA is indicated with an arrow. Residues that are switched around are drawn in bold, and mutation of a crucial K residue mutated to $Q$ is indicated with an asterisk. s-, Peptides derived from squid synapsin sequences.

produced by s-pepA was not attributable to some nonspecific property of the peptide, such as its charge.

Similarly, several peptides derived from the conserved domain $\mathrm{C}$ of synapsins reversibly inhibited release (Table 1). One of these peptides (s-pepC5) profoundly and reversibly inhibited synaptic transmission (Fig. 1D), whereas a control scrambled peptide (scrambled s-pepC5) was without effect (Fig. 1E, Table 2). Finally, a peptide derived from the conserved C-terminal region of domain E fully and reversibly inhibited release, as reported previously for a longer peptide derived from this region (Table 1) (Hilfiker et al., 1998).

In contrast, peptides derived from less-conserved regions of synapsin were relatively ineffective. For example, a peptide from domain B only slightly inhibited synaptic transmission, whereas peptides from domain $\mathrm{V}$ and from the variable nonconserved N-terminal part of domain E had no effect (Table 1). Peptides derived from sequences homologous to those reported to confer calmodulin binding to rat synapsins in vitro (Hayes et al., 1991; Nicol et al., 1997) reversibly inhibited transmission (s-CaM1 and s-CaM2, Table 1), with the peptide derived from the region reported to constitute a high-affinity calmodulin binding site (Nicol et al., 1997) more potent than the peptide derived from the second calmodulin-binding region. Because these calmodulinbinding peptides may act as general calmodulin sinks, depleting cellular levels of calmodulin necessary for exocytosis (Chamberlain et al., 1995; Chen et al., 1999; Quetglas et al., 2002) rather than, or in addition to, interfering with synapsin-calmodulin interactions in vivo, they were not investigated further. A peptide (s-TID3N) encompassing a region of synapsins that appears to interact with the hydrophobic core of the phospholipid bilayer (Cheetham et al., 2001) had the unusual property of enhancing synaptic transmission evoked by presynaptic action potentials (Fig. $1 F$, Table 1). Because of possible nonspecific effects of this peptide on lipid bilayer structure, this reagent was not studied further.

In summary, these observations show that reagents (s-pepA, s-pepC5, and s-pepE) from the three evolutionarily conserved domains (A, C, and E) of squid synapsins specifically interfere with neurotransmitter release. These results indicate that domains $\mathrm{A}, \mathrm{C}$, and $\mathrm{E}$ may undergo interactions with binding partners that are important for neurotransmitter release. The other domains (B and V) may serve roles that do not involve protein-protein interactions; these domains may be structural or may otherwise contribute to the function of squid synapsins. The remainder of our study focused on the functions of domains A, C, and E, using the active peptides from these domains.

\section{Domain A peptide inhibits neurotransmitter release in a phosphorylation-dependent manner} s-pepA contains short sequences defining a consensus phosphorylation site for PKA and CaMKI. Domain A of vertebrate synapsins is phosphorylated at this site (site 1) by both kinases in vitro and in vivo (Huttner and Greengard, 1979; Czernik et al., 1987). To test whether the squid domain A peptide was phosphorylated by PKA and CaMKI, we measured phosphorylation of s-pepA in vitro. The kinetic parameters $K_{\mathrm{m}}$ (the apparent affinity for substrate) and $k_{\text {cat }}$ (the turnover number) were determined from linear regression analysis of Lineweaver-Burk transformations that described the initial rates of phosphorylation as a function of peptide concentration. s-pepA was an excellent substrate for PKA phosphorylation $\left(K_{\mathrm{m}}\right.$ of $22.3 \pm 8 \mu \mathrm{M} ; k_{\text {cat }}$ of $\left.0.97 \pm 0.35 \mathrm{~s}^{-1} ; n=8\right)$ and CaMKI phosphorylation $\left(K_{\mathrm{m}}\right.$ of $103 \pm 14.4 \mu \mathrm{M} ; k_{\mathrm{cat}}$ of $4.3 \pm 0.6 \mathrm{~s}^{-1} ; n=$ 4 ), suggesting that full-length squid synapsins may be substrates for phosphorylation by PKA and CaMKI as well.

To address whether the inhibitory action of s-pepA was dependent on its phosphorylation state, we tested the effects of chemically phosphorylated s-pepA (phospho-s-pepA). This peptide was not capable of undergoing additional phosphorylation by either PKA or CaMKI, indicating the effectiveness of the chemical phosphorylation (Fig. $2 A$ ). No change in neurotransmitter release was detected, even during prolonged injections of phosphos-pepA (Fig. 2B, Table 2), indicating that s-pepA inhibited neurotransmitter release in a sequence- and phosphorylation-dependent manner.

On the basis of primary sequence homology, domain A encompasses the $\mathrm{N}$-terminal 28 residues of vertebrate synapsins. In invertebrates, sequence identity is restricted to a rather short region surrounding phosphorylation site 1 (Hilfiker et al., 1998). Indeed, a shorter version of s-pepA consisting of 11 amino acids encompassing the consensus phosphorylation site (short s-pepA) effectively and reversibly inhibited neurotransmitter release evoked by presynaptic action potentials (Fig. 2 B, Table 2), suggesting that the functionally active region of domain A resides in a short stretch of residues that includes phosphorylation site 1 .

The phosphorylation-dependent inhibition of neurotransmitter release mediated by s-pepA may be attributable to at least two different mechanisms. Domain A of endogenous squid synapsins may interact with a binding partner in a phosphorylationsensitive manner, which would cause this interaction to be disrupted by s-pepA but not by the phosphorylated or scrambled versions of this peptide. Alternatively, s-pepA might inhibit transmitter release indirectly by decreasing the basal activity of PKA, which is important for exocytosis at the squid giant synapse (Hilfiker et al., 2001). In this case, s-pepA could inhibit exocytosis by competing with endogenous PKA (and/or CaMKI) substrates and alter their state of phosphorylation. To distinguish between 

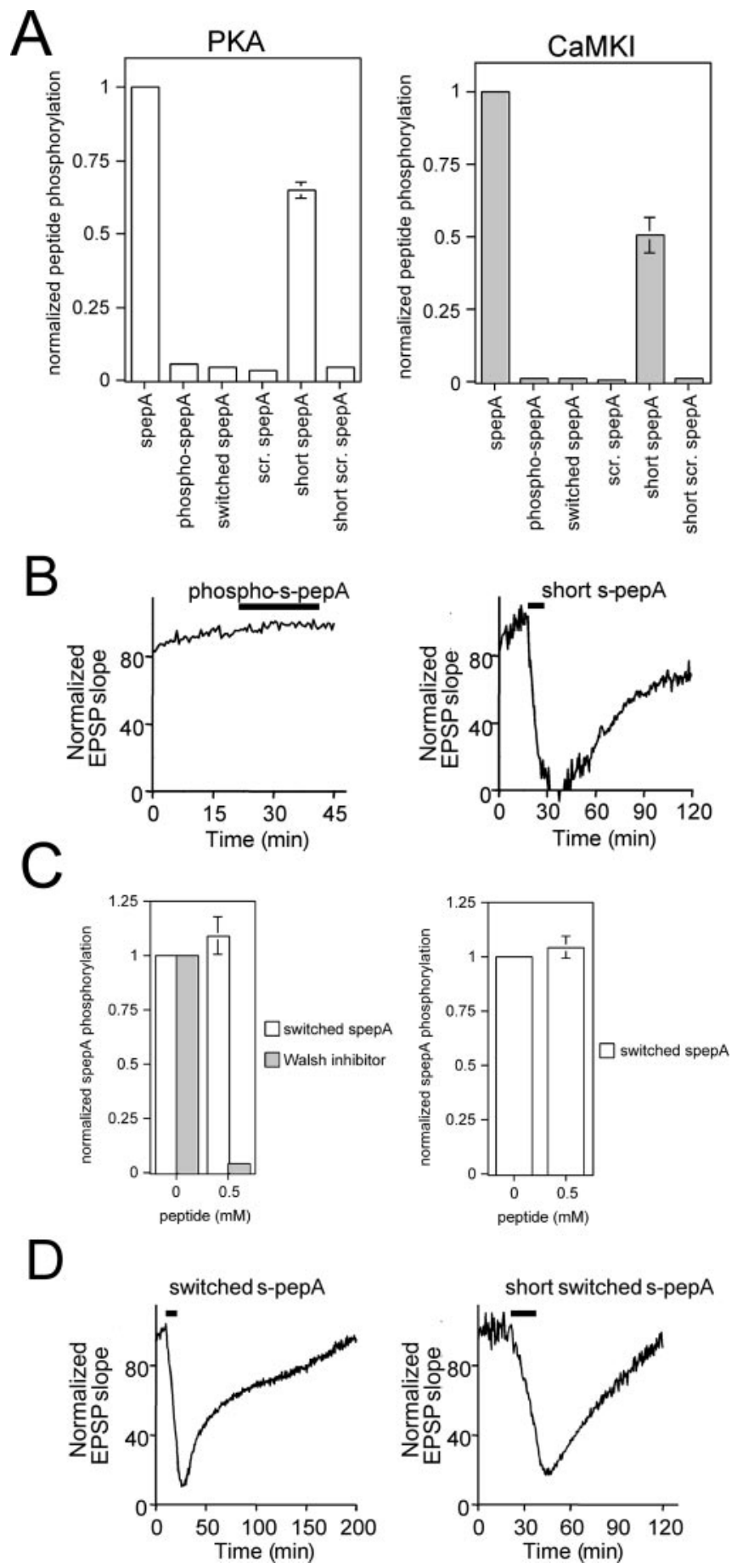

Figure 2. s-pepA inhibits neurotransmitter release in a phosphorylation-dependent manner. $A$, An in vitro peptide phosphorylation experiment. The indicated peptides were subjected to phosphorylation by either PKA (left) or CaMKI (right). The extent of phosphorylation of each peptide (mean $\pm \mathrm{SEM} ; n=3$ ) was normalized to the amount of radioactivity incorporated into s-pepA. Error bars are only shown when larger than the symbols. scr., Scrambled. $\boldsymbol{B}$, phosphos-pepA had no effect on transmitter release. short s-pepA, encompassing the phosphorylation site, reversibly inhibited transmitter release. C, Switched s-pepA does not act as a kinase inhibitor. Experiments were performed under initial rate conditions. The phosphorylation of s-pepA by either PKA (left) or CaMKI (right) was not inhibited by up to $500 \mu \mathrm{m}$ switched s-pepA. As a positive control under the same conditions, $50 \mu \mathrm{MPKL}$-amide (Walsh inhibitor) fully blocked the phosphorylation ofs-pepA by PKA. The extent of phosphorylation of s-pepA (mean \pm SEM; $n=$ 5) was normalized to the amount of radioactivity incorporated into s-pepA in the absence of switched s-pepA or Walsh inhibitor peptides. D, Injection of switched s-pepA (solid bar) reversibly inhibited neurotransmitter release. Injection of short switched s-pepA (solid bar) reversibly inhibited neurotransmitter release. these two possibilities, we designed a peptide that would serve as neither a kinase substrate nor a kinase inhibitor. This was done by altering the location of the phosphorylatable serine residue(s), specifically by shifting the order of residues 9 and 10 with that of residues 11 and 12 (Table 2, switched s-pepA). This peptide was not phosphorylated by either PKA or CaMKI (Fig. $2 A$ ). It also did not inhibit the phosphorylation of s-pepA by either PKA or CaMKI, even if added in a $>100$-fold molar excess (Fig. 2C). Although the peptide did not interact with the kinases, it did cause a robust and reversible inhibition of transmitter release (Fig. 2D, Table 2), as did a shorter version of this peptide (short switched s-pepA) (Fig. 2D, Table 2). Thus, we conclude that s-pepA and short s-pepA exert their effects not by altering basal kinase activities but by interfering with the phosphorylationsensitive binding of domain A to a binding partner. This binding interaction apparently is mediated by six $\mathrm{N}$-terminal residues that overlap with the consensus phosphorylation site.

\section{Mechanism of domain A peptide action}

Nearly all known perturbations of synapsin function, including injection of a peptide from domain E, speed up the rate of synaptic depression (Pieribone et al., 1995; Rosahl et al., 1995; Hilfiker et al., 1998; Humeau et al., 2001). Because the rate of depression is thought to reflect a dynamic equilibrium between the readily releasable and reserve pools of synaptic vesicles, this acceleration of depression is taken as an indication that the size of the reserve pool is reduced when synapsin is impaired (Pieribone et al., 1995; Rosahl et al., 1995; Hilfiker et al., 1998; Humeau et al., 2001). To examine the contribution of domain A to this role of synapsin, synaptic depression was elicited by trains of presynaptic action potentials before and while reducing synaptic transmission by either injection of s-pepA (Fig. 3A) or lowering external calcium concentration (Swandulla et al., 1991). During these trains of synaptic activity, the amount of transmitter release per presynaptic action potential declined with an exponential time course (Fig. 3B). As expected, reducing synaptic transmission by lowering external calcium concentration caused depression to develop more slowly (Fig. 3B), with the time constant of depression inversely dependent on the initial level of transmitter release (Fig. 3C). Surprisingly, s-pepA had no effect on synaptic depression at a given level of release (Fig. $3 B, C$ ). This provides an indication that the peptide is not affecting the reserve pool of synaptic vesicles.

To further consider the possible effects of s-pepA on vesicle pool size, we used electron microscopy to examine the effect of this peptide on presynaptic ultrastructure. During the injection of s-pepA, synaptic transmission was monitored, and the terminals were fixed after the peptide had inhibited EPSP slope by $>85 \%$ to ensure any maximal structural effect. Control terminals were treated similarly, except that they were injected with a similar amount of scrambled peptide that did not inhibit synaptic transmission. The ultrastructure of terminals injected with s-pepA appeared identical to terminals injected with control peptide (Fig. 4A,B). We looked for more subtle ultrastructural effects by measuring the distribution of synaptic vesicles in the vicinity of the active zone (Hess et al., 1993). s-pepA affected neither the number of synaptic vesicles (Fig. 4C) nor their spatial distribution within the presynaptic terminal (Fig. 4D). This lack of change in vesicle trafficking or number indicates that domain $\mathrm{A}$ does not appear to regulate the reserve pool of synaptic vesicles.

Interfering with synapsins has been reported to slow the kinetics of neurotransmitter release (Hilfiker et al., 1998; Humeau et al., 2001). To study whether s-pepA affected neurotransmitter 


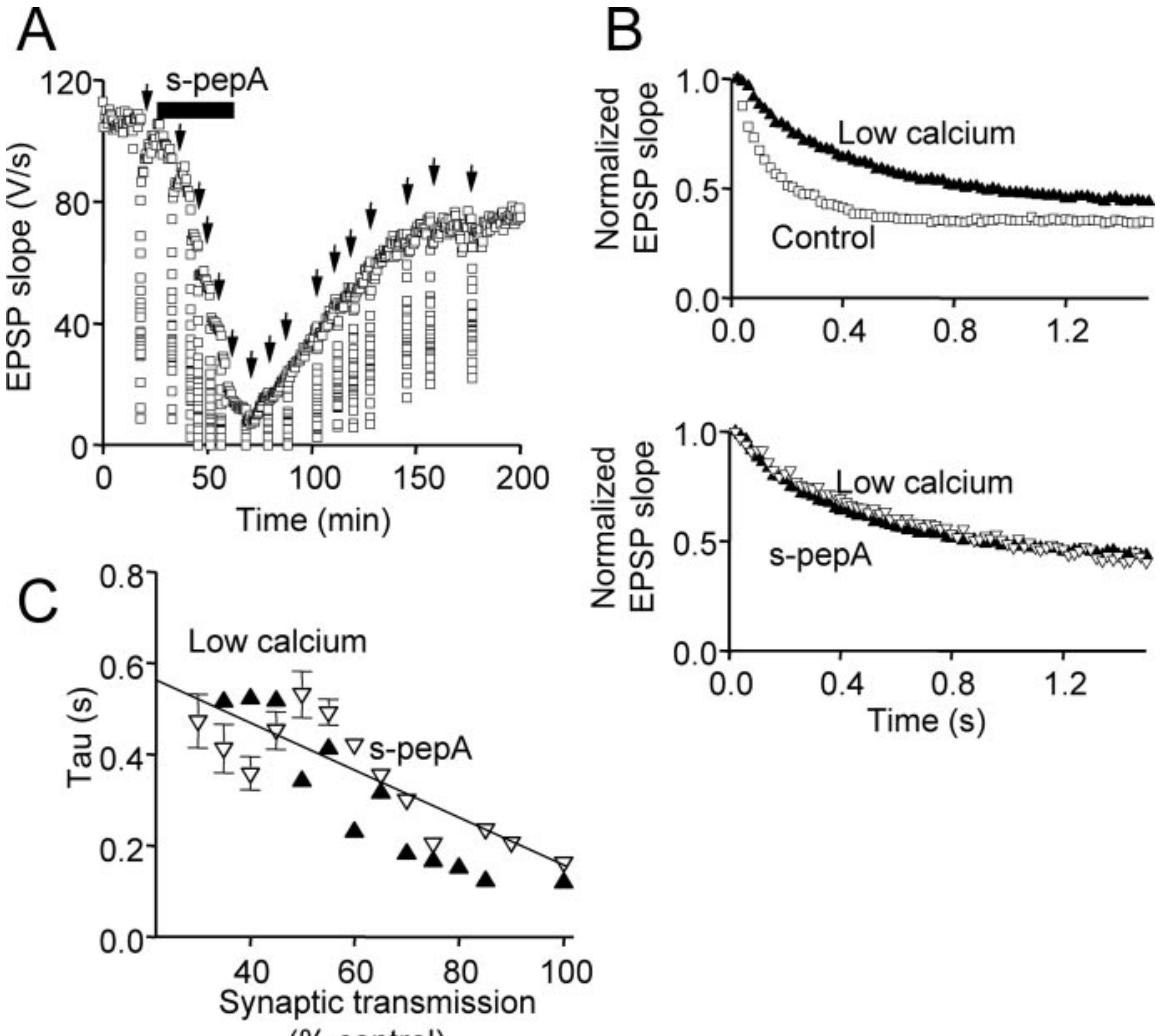

(\% control)

Figure 3. s-pepA has no effect on synaptic depression. $\boldsymbol{A}$, Trains of stimuli (arrows) were applied while injecting s-pepA. $\boldsymbol{B}$, The time course of depression during trains was determined from the first 75 responses when transmission was normal (open squares; $n=8$ ), reduced to $50 \%$ by lowered extracellular calcium (filled triangles; $n=3$ ), or reduced to $50 \%$ by injection of s-pepA (open inverted triangles; $n=6$ ). The traces shown represent mean postsynaptic responses, which were normalized to the last response before the train. C, Comparison of effects of lowered external calcium and s-pepA injection on the time constants for depression calculated from data of the type illustrated in $\boldsymbol{B}$. Synaptic depression was elicited at various time points during inhibition of neurotransmitter release by either lowering extracellular calcium (filled triangles; $n=3$ ) or injection of s-pepA (open inverted triangles; $n=4$ ). Values obtained within a $5 \%$ difference in synaptic transmission were binned. The time constants are means \pm SEM of at least two and maximally 12 individual traces. Error bars (indicating SEM) are only visualized when larger than the symbol size.

release kinetics, we used voltage clamping to measure EPSCs evoked by presynaptic action potentials. s-pepA did not slow the kinetics of EPSCs, with EPSC onset being $97 \pm 2 \%$ of control and EPSC decay being $103 \pm 4 \%$ of control after injection of peptide $(n=3)$ (Fig. $4 E, F)$. In summary, it appears that domain A participates in a phosphorylation-sensitive interaction that does not alter the reserve pool of synaptic vesicles or the kinetics of transmitter release.

\section{Domain C peptide inhibits neurotransmitter release}

We explored the function of domain $\mathrm{C}$ by further characterizing the physiological effects of s-pepC5. Synapsin domain C shows striking structural similarity to members of a family of ATP-using enzymes (Esser et al., 1998; Brautigam et al., 2004). Members of this ATP-grasp family contain a flexible, catalytically essential loop ("multifunctional loop") that is unstructured in the unliganded enzyme but assumes a fixed conformation during substrate binding. Such a multifunctional loop has also been found in the crystal structure of domain $\mathrm{C}$ of rat synapsin, and the amino acid sequence of s-pepC5 (equivalent to residues 325-347 in rat synapsin I) encompasses all residues involved in forming the multifunctional loop exposed on the surface of the protein (equivalent to residues 330-343 of rat synapsin I). In addition, a basic residue in this loop of domain $\mathrm{C}$ of synapsin has been shown to be important for ATP binding (Brautigam et al., 2004). To test the functional importance of this residue, we generated a mutant version of s-pepC5 (mutant s-pepC5) with a glutamine residue replacing the positively charged lysine residue within the loop. Injecting this pointmutated peptide inhibited release by an average of $14 \pm 8 \%(n=3)$, whereas injecting comparable amounts of active s-pepC5 inhibited release by an average of $80 \pm 5 \%(n=14)$ (Fig. 5A, Table 2). These data further confirm that the effects of s-pepC5 were highly sequence specific.

\section{Domain $\mathrm{C}$ regulates the reserve pool of vesicles}

To examine the contribution of domain $C$ to the maintenance of the reserve pool of synaptic vesicles, synaptic depression was elicited by trains of presynaptic action potentials as described above. EPSPs of comparable size depressed much more rapidly after s-pepC5 injection than when lowered external calcium was used to reduce transmitter release (Fig. 5B). This acceleration of depression indicates that disruption of synapsin function by s-pepC5 injection reduces a pool of vesicles available for release.

We also used electron microscopy to examine the effect of s-pepC5 on presynaptic ultrastructure. s-pepC5-injected terminals exhibited a decrease in the total number of vesicles within the active zone compared with terminals injected with a scrambled control peptide (Fig. 5C,D). The total number of vesicles within 500 $\mathrm{nm}$ of the plasma membrane was reduced by $25 \%(p<0.001)$ (Fig. $5 E)$. A detailed morphometric analysis indicated that s-pepC5 preferentially reduced the size of the distal, reserve pool of vesicles clustered in the vicinity of the active zone (Pieribone et al., 1995) but did not alter the number of proximal, docked vesicles (Fig. $5 F$ ). These data are consistent with the observation that s-pepC5 injection accelerates synaptic depression and indicate that the size of the reserve pool of vesicles depends on a function of synapsin that involves domain C.

\section{Domain $\mathrm{C}$ peptide regulates a post-docking step of the release process}

Besides reducing reserve pool size, s-pepC5 also seemed to affect neurotransmitter release more directly. First, the number of docked vesicles (those within $50 \mathrm{~nm}$ of the active zone), which is thought to include or represent a readily releasable pool of vesicles (Parsons et al., 1995; Schikorski and Stevens, 1997), was unchanged during s-pepC5 injection ( $94 \%$ of control; $p>0.5$ ) (Fig. $5 F$ ), whereas neurotransmitter release was inhibited (Fig. $1 D$ ). This indicates that s-pepC5 inhibits the ability of docked synaptic vesicles to fuse with the plasma membrane.

Consistent with the reduction of EPSP amplitude and rate of rise (Fig. 1D), injection of a submaximal concentration of s-pepC5 reduced the peak amplitude of EPSCs by $61 \pm 6 \%(n=$ 3) (Fig. 6A). However, s-pepC5 also slowed both the onset (by 
A
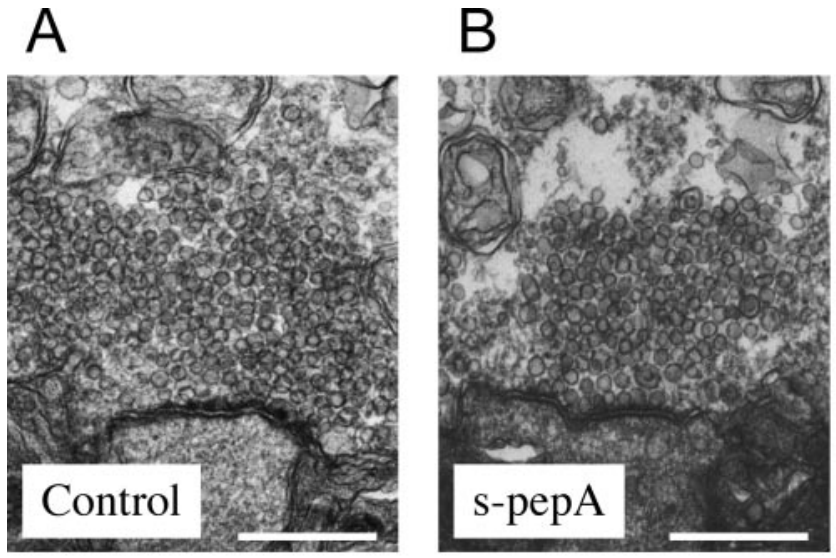

C
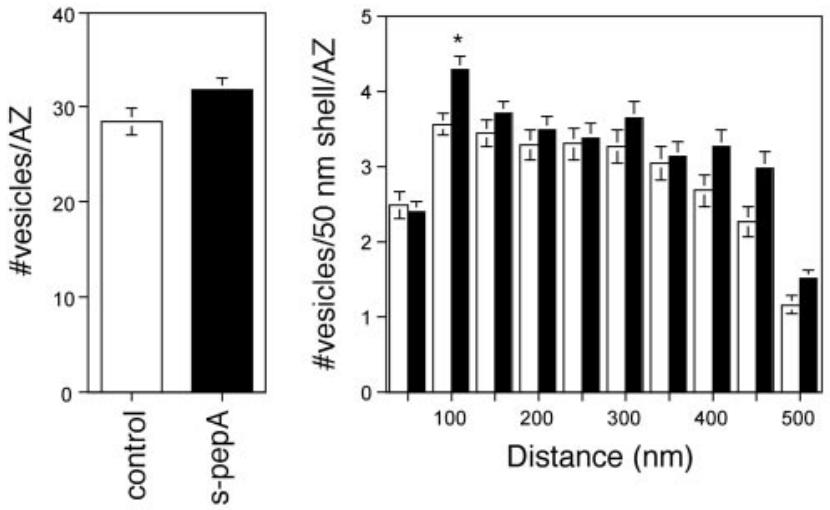

E
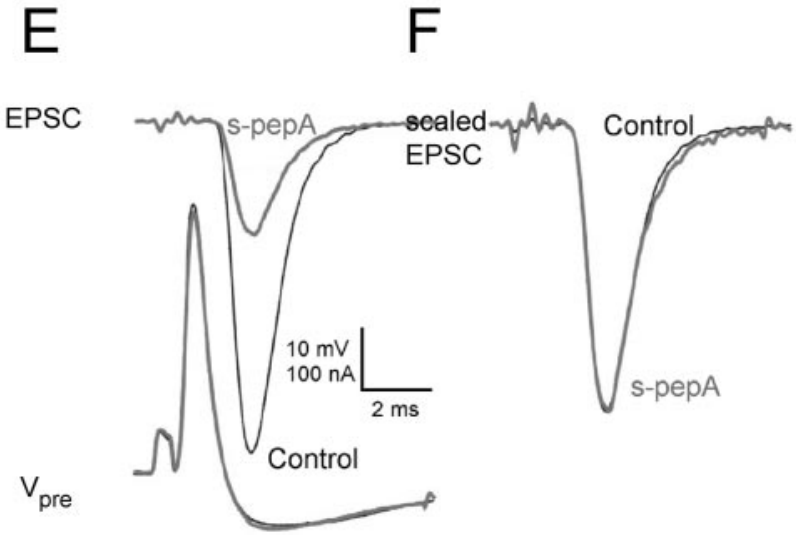

Figure 4. s-pepA has no effect on presynaptic ultrastructure or on the kinetics of neurotransmitter release. Electron micrographs of terminals injected with control $(\boldsymbol{A})$ or active s-pepA $(\boldsymbol{B})$ are shown. Scale bars, $0.5 \mu \mathrm{m}$. $\boldsymbol{C}$, Mean \pm SEM number of synaptic vesicles within a $500 \mathrm{~nm}$ shell starting from the plasma membrane of active zones (AZs) injected with control peptide (control; white bar) or s-pepA (black bar). D, Distribution of synaptic vesicles ( $50 \mathrm{~nm}$ shell) per active zone (AZ) after injection of scrambled peptide (white bars; $n=187$ active zones, 2 terminals) or s-pepA (black bars; $n=194$ active zones, 2 terminals). ${ }^{*} p<0.01$ (Student's $t$ test). $\boldsymbol{E}$, Presynaptic potentials $\left(V_{\text {pre }}\right)$ and postsynaptic currents (EPSC) before (black line) and during (gray line) injection of s-pepA. $\boldsymbol{F}$, EPSCs from $\boldsymbol{E}$ scaled to identical peak amplitudes show no change in EPSC time course with s-pepA. Results shown are representative of three independent experiments.

$19 \pm 1 \%$ ) and the decay (by $26 \pm 9 \%)$ of the EPSC $(n=3)$ (Fig. $6 B)$. These kinetic effects of s-pepC5 were reversible and depended on the amount of peptide injected into the presynaptic terminal (data not shown). Because s-pepC5 was injected directly into the presynaptic terminal, this peptide seemed to alter EPSC
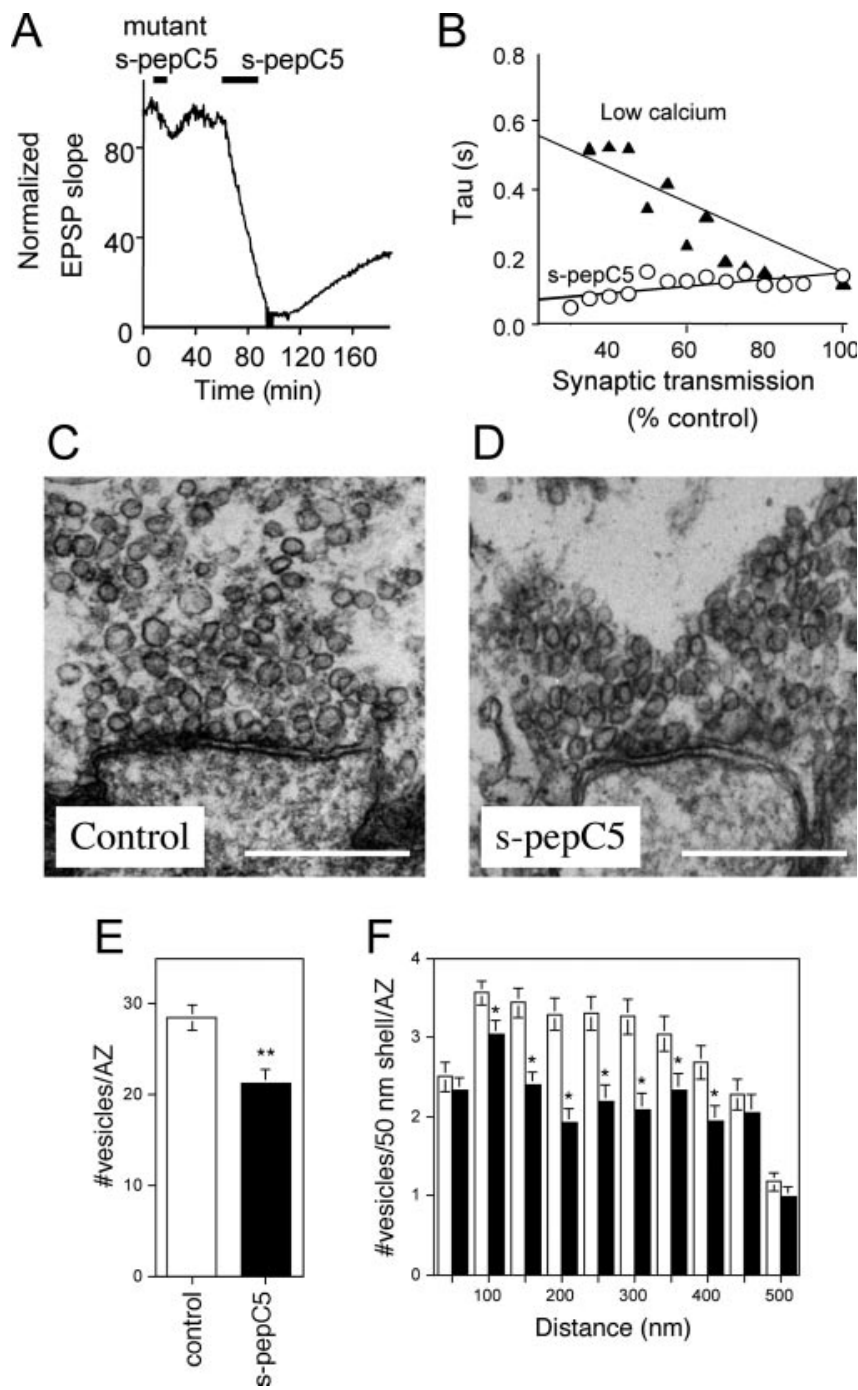

Figure 5. s-pep 5 enhances synaptic depression and decreases the number of synaptic vesicles. $\boldsymbol{A}$, Mutant s-pep $C 5$ was much less effective in inhibiting release compared with s-pepC5 (right), although comparable amounts of each peptide were sequentially injected into the same synapse. $\boldsymbol{B}$, Time constants for depression were calculated as described in the legend to Figure 4. Synaptic depression was elicited at various time points during inhibition of neurotransmitter release by either lowering extracellular calcium (filled triangles; $n=3$ ) or injecting s-pepC5 (open circles; $n=10$ ). Values obtained within a $5 \%$ difference in synaptic transmission were binned. The time constants are means \pm SEM of at least two and maximally 15 individual traces. Error bars (indicating SEM) are only visualized when larger than the symbol size. Electron micrographs of terminals injected with scrambled s-pepC5 (C) and s-pepC5 (D) are shown. Scale bars, $0.5 \mu \mathrm{m}$. $\boldsymbol{E}$, Mean \pm SEM number of synaptic vesicles within a $500 \mathrm{~nm}$ shell starting from the plasma membrane of active zones (AZs) injected with scrambled s-pepC5 (control; white bar) or s-pepC5 (black bar). $F$, Distribution of synaptic vesicles ( $50 \mathrm{~nm}$ shell) per active zone (AZ) after injection of scrambled s-pepC5 (white bars; $n=187$ active zones, 2 terminals) or s-pepC5 (black bars; $n=188$ active zones, 2 terminals). ${ }^{*} p<0.01$; ${ }^{* *} p<0.001$ (Student's $t$ test).

kinetics by changing the time course of transmitter release rather than by modifying postsynaptic glutamate receptors or transporters. These changes in kinetics are not attributable to the reductions in transmitter release or vesicle pool size per se, because many treatments that reduce neurotransmitter release (Bommert et al., 1993; Hess et al., 1993; Hunt et al., 1994; DeBello et al., 1995; O’Connor et al., 1997; Burns et al., 1998) or vesicle pool size (Hess et al., 1993; DeBello et al., 1995; Burns et al., 1998) do not slow EPSC time course (Schweizer et al., 1998). Together, these data suggest that domain $\mathrm{C}$ of synapsins is not only required for maintaining vesicle clusters at the active zone but also partici- 
A

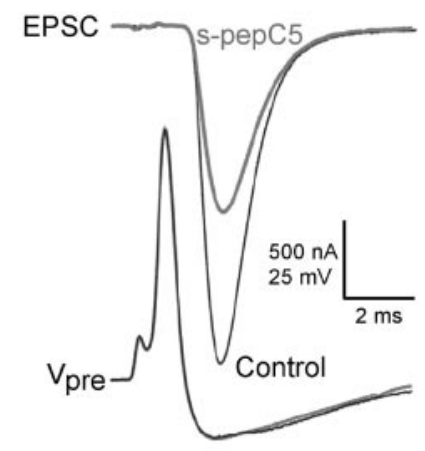

Figure 6. s-pepC5 slows the kinetics of neurotransmitter release. $\boldsymbol{A}$, Presynaptic potentials $\left(V_{\text {pre }}\right)$ and postsynaptic currents (EPSC) before (black line) and during (gray line) injection of s-pepC5. B, EPSCs from $\boldsymbol{A}$ scaled to identical peak amplitudes show the slowing of EPSC time course with s-pepC5. Results shown are representative of three independent experiments.

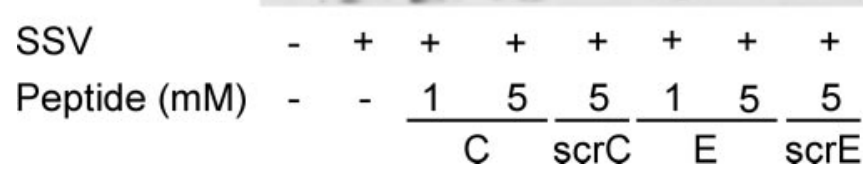

Figure 7. s-pepC5 has no effect on synapsin-synaptic vesicle interactions. Purified synapsin I was incubated with rat-derived, synapsin-depleted synaptic vesicles (SSV) in the absence (-) or presence $(+; 1$ or $5 \mathrm{~mm}$ final concentration) of rat synapsin I pepC5 (C), rat synapsin I pepE $(E)$, or scrambled (scr) versions thereof. Synaptic vesicles were recovered by high-speed centrifugation, and the amounts of synapsin I and synaptophysin (data not shown) in the pellets were analyzed by immunoblotting.

pates more directly in reactions that determine the kinetics of neurotransmitter release.

\section{Domain C peptide does not affect synapsin binding to synaptic vesicles}

The changes in synaptic transmission and presynaptic ultrastructure produced by the domain C peptide s-pepC5 were identical to those produced by injecting s-pepE, a peptide from domain $\mathrm{E}$ (Hilfiker et al., 1998). The similarity in the actions of structurally unrelated peptides from two different domains substantiates that these effects are attributable to specific impairments of synapsin function and, thus, that synapsins are required to both regulate a reserve pool of synaptic vesicles and modulate a second step that controls the kinetics of neurotransmitter release. Having two distinct and specific peptide reagents that elicit identical presynaptic phenotypes, we next used in vitro binding assays to determine how these peptides interfered with the biochemical functions of synapsins. We compared the actions of these two peptides with each other and with the actions of s-pepA, which also affects transmitter release but has physiological and ultrastructural effects quite different from those of the other two peptides.

The best studied interactions of synapsins are binding to synaptic vesicles and to actin (Schiebler et al., 1986; Bähler and Greengard, 1987; Bähler et al., 1989; Benfenati et al., 1989a,b, 1992a,b, 1993a,b; Thiel et al., 1990; Chilcote et al., 1994; Ceccaldi et al., 1995; Hosaka et al., 1999; Hurley et al., 2004). We deter-
A

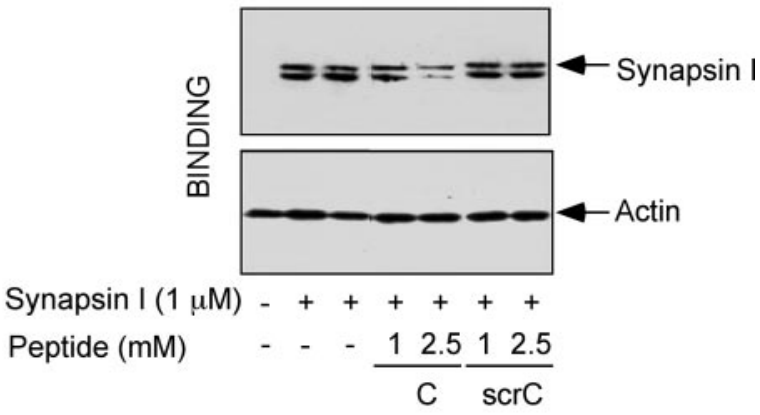

B

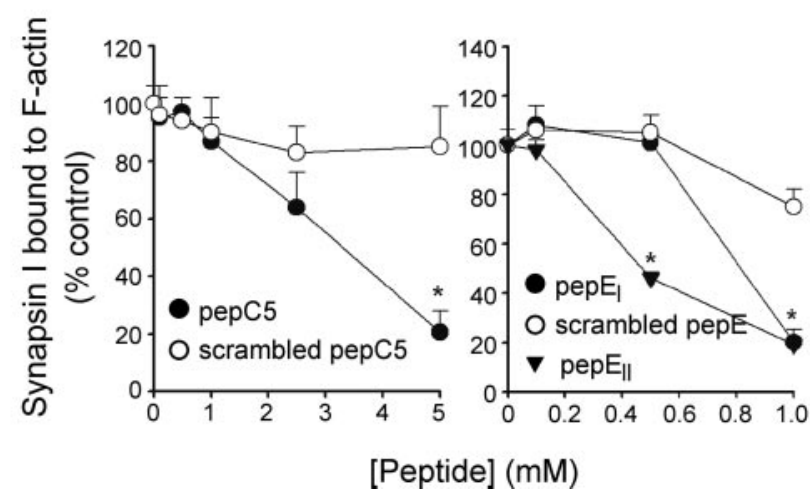

Figure 8. s-pepC5 interferes with synapsin-F-actin interactions. $A$, Purified synapsin I was incubated with $\mathrm{F}$-actin in the absence $(-)$ or presence $(+)$ of various millimolar concentrations of either rat synapsin I pepC (C) or scrambled pepC (scrC), followed by high-speed centrifugation. Samples of F-actin pellets, normalized for the F-actin content, were subjected to immunoblotting for synapsin and actin. B, Dose-dependent inhibition of synapsin I binding to F-actin by rat synapsin I pepC (pepC5), scrambled rat synapsin I pepC (scrambled pepC5), rat synapsin I pepE (pep $\left.E_{1}\right)$, scrambled rat synapsin I pepE (scrambled pepE), or rat synapsin II pepE (pepE $E_{\|}$) (Hilfiker et al., 1998). The amounts of immunoreactive synapsin I bound to F-actin in the absence or presence of various concentrations of the peptides and normalized for equal F-actin concentration are expressed as the percentage of the binding observed in the absence of peptides (means $\pm \mathrm{SEM} ; n=6$ ). ${ }^{*} p<0.01$ (Dunnett's test).

mined whether the domain $\mathrm{C}$ and E peptides prevented synapsins from binding to synaptic vesicles. The binding of exogenous synapsin I to highly purified, synapsin-depleted synaptic vesicles (Huttner et al., 1983) was not significantly affected by the presence of either scrambled control peptides or by active domain $\mathrm{C}$ and E peptides, even at concentrations as high as $5 \mathrm{~mm}$ (Fig. 7). The binding of synapsin I to vesicles also was not affected when corresponding concentrations of the two active peptides were added simultaneously (data not shown). Thus, it is unlikely that the domain $\mathrm{C}$ and $\mathrm{E}$ peptides inhibit transmitter release by interfering directly with the binding of synapsins to synaptic vesicles.

Domain C peptide interferes with synapsin-actin interactions Synapsins bind to F-actin, an interaction that has been proposed to play a key role in the synapsin-mediated regulation of synaptic vesicle trafficking (Greengard et al., 1993). In addition, synapsins bundle preformed actin filaments (Bähler and Greengard, 1987; Petrucci and Morrow, 1987; Chilcote et al., 1994) and enhance the polymerization of actin monomers into filaments (Fesce et al., 1992; Valtorta et al., 1992), suggesting that synapsins may also regulate the dynamics of actin-based networks within presynaptic terminals (Benfenati et al., 1992a).

We studied the effects of pepC5 on binding of synapsin to 
F-actin by incubating purified synapsin I with preformed actin filaments. Binding was then assessed by measuring the amount of synapsins that copelleted with F-actin after high-speed centrifugation. pepC5 caused a concentration-dependent inhibition of synapsin I binding to actin filaments, whereas scrambled pepC5 had little effect (Fig. $8 A, B$ ). Approximately $80 \%$ of synapsin I was displaced by $5 \mathrm{~mm}$ pepC5 (Fig. $8 \mathrm{~B}$ ), a concentration that should fully inhibit neurotransmitter release. Likewise, rat synapsin I pepE caused a specific and concentration-dependent inhibition of synapsin I binding to actin filaments (Fig. $8 \mathrm{~B}$ ). In agreement with their functional and sequence similarity (Hilfiker et al., 1998), rat synapsin I pepE, rat synapsin II pepE, and squid synapsin pepE all inhibited the binding of synapsin to F-actin in a concentration-dependent manner, whereas their respective scrambled counterparts had little effect (Fig. $8 B$ and data not shown). Furthermore, both pepC5 and pepE specifically interfered with the ability of synapsin I to bundle F-actin filaments (Fig. $9 A$ and data not shown) and to enhance the polymerization of G-actin into filaments (Fig. $9 B$ and data not shown). In summary, both domain $\mathrm{C}$ and $\mathrm{E}$ peptides specifically interfered with the binding of synapsin I to actin filaments. This indicates a possible molecular mechanism for the inhibition of neurotransmitter release by these peptides.

In contrast, even high concentrations of s-pepA (up to $5 \mathrm{~mm}$ ) did not affect the binding of exogenous synapsin I to synapsin-depleted synaptic vesicles (Fig. $10 \mathrm{~A}$ ) and had no effect on synapsin-Factin interactions (Fig. $10 \mathrm{~B}, \mathrm{C}$ and data not shown). This provides another indication that s-pepA inhibits neurotransmitter release through a mechanism distinct from that of s-pepC5 or s-pepE.

\section{Discussion}

We used the squid giant synapse to analyze the function of various domains of synapsins. Presynaptic injection of peptides encompassing all domains of synapsins revealed that the three evolutionarily conserved domains (A, C, and E) play distinct and overlapping roles in the synapsin-dependent regulation of neurotransmitter release.

\section{Function of synapsin domain A}

We found that a peptide derived from domain A of synapsins inhibited neurotransmitter release in a phosphorylationdependent manner without effects on vesicle pool size or neurotransmitter release kinetics. The molecular mechanism involved in the inhibitory effect is unclear, because this peptide had no effect on either synapsin-actin or synapsin-vesicle interactions. Domain A is known to interact with phospholipids, and this interaction is neutralized by phosphorylation (Hosaka et al., 1999); this may underlie the effect of the domain A peptide on transmitter release. Interfering with synapsin-lipid interactions may result in a subtle decrease in the affinity of binding of synapsins to synaptic vesicles, which might not be detectable in biochemical experiments yet still affect transmitter release evoked by single action potentials. Additional work is necessary to clarify the mechanism of domain A peptide action.
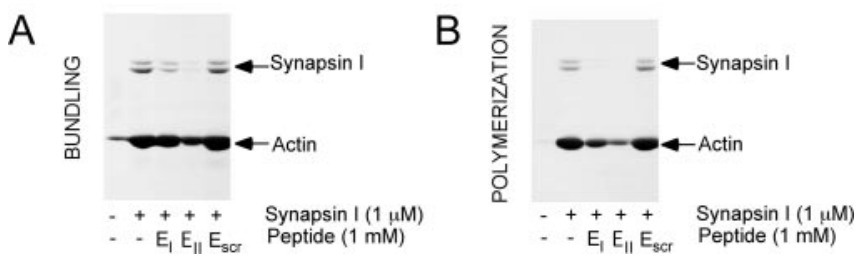

Figure 9. Peptide effect on synapsin-mediated F-actin bundling and $\mathrm{G}$-actin polymerization. Purified synapsin I was incubated with either F-actin $(\boldsymbol{A})$ or $\mathrm{G}$-actin $(\boldsymbol{B})$ in the absence (-) or presence $(+)$ of $1 \mathrm{~mm}$ rat synapsin I pepE $\left(E_{1}\right)$, rat synapsin II pepE $\left(E_{||}\right)$, or scrambled rat synapsin I pepE $\left(E_{s c r}\right)$ (Hilfiker et al., 1998). F-actin bundling $(\boldsymbol{A})$ was analyzed by low-speed centrifugation to selectively pellet bundles of filaments. G-actin polymerization (B) was assessed by high-speed centrifugation to pellet actin filaments. Pellet fractions are shown after SDS-PAGE and Coomassie blue staining.
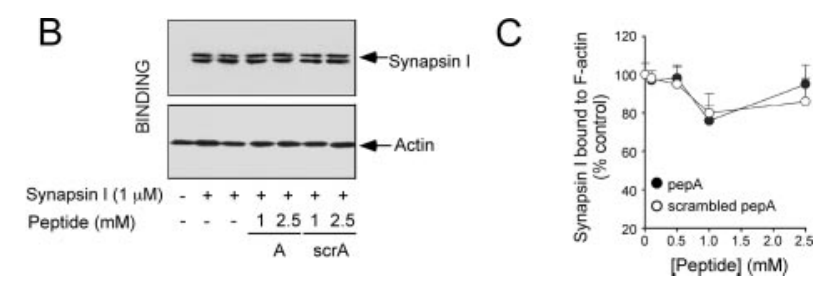

Figure 10. s-pepA does not interfere with synapsin-actin or synapsin-synaptic vesicle interactions. $\boldsymbol{A}$, Purified synapsin I was (A) or scrambled pepA (scrA), followed by high-speed centrifugation. Samples of F-actin pellets, normalized for F-actin content, 列 peptides and normalized for equal F-actin concentration are expressed as the percentage of the binding observed in the absence of peptides (means \pm SEM; $n=6) .{ }^{*} p<0.01$ (Dunnett's test).

Synapsin domains $\mathrm{C}$ and $\mathrm{E}$ maintain a reserve pool of vesicles Numerous studies indicate that synapsins regulate the size of a reserve pool of vesicles away from the plasma membrane (Li et al., 1995; Pieribone et al., 1995; Takei et al., 1995; Hilfiker et al., 1998; Humeau et al., 2001). This ultrastructural change is paralleled by an increase in synaptic depression observed during highfrequency stimulation (Pieribone et al., 1995; Rosahl et al., 1995; Hilfiker et al., 1998; Humeau et al., 2001), suggesting that the synapsin-dependent reserve pool of vesicles away from the plasma membrane is required to maintain release under these conditions. Our results have implicated domains $\mathrm{C}$ and $\mathrm{E}$ in this presynaptic function of synapsins. A peptide derived from the largest, conserved domain $\mathrm{C}$ of synapsins inhibited neurotransmitter release evoked by presynaptic action potentials, accelerated synaptic depression elicited by high-frequency stimulation, and depleted a pool of synaptic vesicles located away from the plasma membrane. The physiological and ultrastructural changes mediated by this peptide were identical to those seen with a peptide derived from domain $\mathrm{E}$, which is the C-terminal part of squid synapsins and mammalian A-type synapsin isoforms (Hilfiker et al., 1998). Thus, it appears that domains C and E participate in the maintenance of the reserve pool of synaptic vesicles by synapsins.

Our observations that domain $\mathrm{C}$ and $\mathrm{E}$ peptides displayed identical effects on presynaptic physiology and ultrastructure suggest that these two peptides interfere with the same interaction of synapsins. In fact, both of these peptides selectively and specifically compete for the binding of synapsin to F-actin. This indicates that both domains either directly or indirectly mediate the binding of synapsins to presynaptic actin filaments. In agree- 
ment with this conclusion, domain mapping studies have shown that a fragment corresponding to the middle region of synapsin I, encompassing the sequence of s-pepC5, binds to F-actin, whereas a fragment corresponding to its C-terminal region was inactive (Bähler et al., 1989). The fragment corresponding to both middle and C-terminal regions exhibited actin binding and bundling activities comparable with those of holosynapsin I. This suggests that the C-terminal region, which contains domain E, may adopt a different conformation in the presence of domain C (Bähler et al., 1989). Such intramolecular interactions of synapsin domains have also been postulated to be important for targeting of synapsins (Gitler et al., 2004a). The present correlation between the effects of these peptides on transmitter release, vesicle localization, and interactions with actin indicates that binding to presynaptic actin filaments underlies the role of synapsins in regulating the availability of synaptic vesicles for neurotransmitter release. It is tempting to speculate that this arises from synapsin-dependent tethering of synaptic vesicles to actin filaments adjacent to the plasma membrane, as has been proposed previously (Greengard et al., 1993).

The role of actin in the synaptic vesicle cycle is controversial (Doussau and Augustine, 2000). Various studies have led to proposals that actin has no presynaptic function (Job and Lagnado, 1998) or that actin plays negative (Wang et al., 1996; Bernstein et al., 1998; Morales et al., 2000; Sankaranarayanan et al., 2003) or positive (Kuromi and Kidokoro, 1998; Cole et al., 2000; Sakaba and Neher, 2003) roles in synaptic vesicle mobilization. It has also been proposed that actin is involved in other aspects of vesicle recycling (Shupliakov et al., 2002). These discrepancies may be attributable to the types and/or sizes of the synapses studied. For example, disruption of actin depletes the presynaptic cluster of vesicles at the giant lamprey synapse (Shupliakov et al., 2002) yet has no effects on vesicle pool size at small hippocampal synapses (Sankaranarayanan et al., 2003). Because the amount of free space surrounding the vesicle cluster is small at hippocampal synapses, dilution of vesicles may not occur after actin is disrupted. In contrast, the large amount of free space surrounding vesicle clusters could allow depletion of reserve pool vesicles after disruption of the actin cytoskeleton at giant synapses (Shupliakov et al., 2002).

\section{Synapsin domains $\mathrm{C}$ and $\mathrm{E}$ regulate release kinetics}

An additional action of synapsins, downstream of clustering the reserve pool of vesicles, is indicated by observations that interfering with synapsins slows the kinetics of neurotransmitter release (Hilfiker et al., 1998; Humeau et al., 2001). This has led to the proposal that synapsins exhibit actions downstream of vesicle docking that cause either a desynchronization of neurotransmitter release or a change in the gating of fusion pores.

We found that a peptide from domain C slows release kinetics, as does a domain E peptide (Hilfiker et al., 1998). Given that these two domains are involved in maintaining vesicles in the reserve pool, it is possible that the changes in release kinetics are a secondary consequence of depleting the reserve pool. Alternatively, the kinetic changes could arise from a more direct effect of synapsins on a membrane-associated pool of releasable vesicles, as postulated previously. Although approximately half of synapsin molecules dissociate from synaptic vesicles during synaptic activity (Sihra et al., 1989; Torri-Tarelli et al., 1992; Hosaka et al., 1999; Chi et al., 2001, 2003), the remainder stays bound to vesicles close to and/or attached to the membrane (Bloom et al., 2003). This would allow synapsins to regulate the kinetics of transmitter release downstream of vesicle docking.
Because both domains $\mathrm{C}$ and $\mathrm{E}$ interact with actin, interfering with their function might change release kinetics by interfering with endogenous actin-synapsin interactions or could be downstream of their effects on synapsin-actin interactions. It is interesting to note that a mutant version of s-pepC5, in which a basic residue was mutated to a glutamine, only moderately inhibited release compared with the active peptide. This basic residue has been shown to be important for ATP binding of synapsin I (Brautigam et al., 2004), and similar basic residues are implicated in substrate binding in the surface-exposed multifunctional loop of other members of the ATP-grasp family of enzymes that are structurally related to synapsin domain C (Tanaka et al., 1992). The effect of s-pepC5 on transmitter release is unlikely attributable to its binding of ATP, because residues beyond those in the peptide are important for stabilizing the bound state of ATP (Brautigam et al., 2004). Furthermore, reducing ATP levels within the presynaptic terminal would slow the synaptic delay significantly (Adams et al., 1985), which we did not observe after microinjection of s-pepC5. However, the kinetic effects of the domain $\mathrm{C}$ and $\mathrm{E}$ peptides could arise from interference with some enzymatic function of synapsins.

\section{Comparison with genetic knock-out studies}

Knocking out mouse genes for synapsins II or III affects synaptic depression (Rosahl et al., 1995; Feng et al., 2002; Gitler et al., 2004 b), consistent with the physiological actions of peptides that interfere with domains C or E. Perturbing domains A, C, or E also affects basal transmitter release, which parallels the decline in basal release of GABA reported in mouse hippocampal neurons in which all three synapsin genes have been knocked out (Gitler et al., 2004b). Deletion of all three synapsin genes does not affect basal release of glutamate (Gitler et al., 2004b), which contrasts with the effects of synapsin peptides at the glutamatergic squid synapse. Why the effects of disturbing synapsin function depend on the type of synapse is not yet clear. One variable may be the rate of spontaneous transmitter release. Disturbing synapsin function in synapses with high rates of spontaneous neurotransmitter release, such as the squid giant synapse, may have more effect on basal release because the high spontaneous release may require ongoing traffic from the reserve pool of synaptic vesicles.

In conclusion, our data indicate that synapsins regulate both vesicle pool size and transmitter release kinetics at the squid giant synapse. This regulation depends on domains $\mathrm{C}$ and $\mathrm{E}$ of synapsins and may involve an actin-mediated tethering of synapsins close to the plasma membrane at the active zone. Domain A has a different function that affects transmitter release via a mechanism that remains to be determined. Thus, different domains of synapsins make different contributions to the actions of this multifunctional regulator of the presynaptic terminal.

\section{References}

Adams DJ, Takeda K, Umbach JA (1985) Inhibitors of calcium buffering depress evoked transmitter release at the squid giant synapse. J Physiol (Lond) 369:145-159.

Augustine GJ, Charlton MP, Smith SJ (1985) Calcium entry into voltageclamped presynaptic terminals of squid. J Physiol (Lond) 367:143-162.

Bähler M, Greengard P (1987) Synapsin I bundles F-actin in a phosphorylation-dependent manner. Nature 326:704-707.

Bähler M, Benfenati F, Valtorta F, Czernik AJ, Greengard P (1989) Characterization of synapsin I fragments produced by cysteine-specific cleavage: a study of their interactions with F-actin. J Cell Biol 108:1841-1849.

Baines AJ, Bennett V (1985) Synapsin I is a spectrin-binding protein immunologically related to erythrocyte protein 4.1. Nature 315:410-413.

Baines AJ, Bennett V (1986) Synapsin I is a microtubule-bundling protein. Nature 319:145-147. 
Benfenati F, Greengard P, Brunner J, Bähler M (1989a) Electrostatic and hydrophobic interactions of synapsin I and synapsin I fragments with phospholipid bilayers. J Cell Biol 108:1851-1862.

Benfenati F, Bähler M, Jahn R, Greengard P (1989b) Interactions of synapsin I with small synaptic vesicles: distinct sites in synapsin I bind to vesicle phospholipids and vesicle proteins. J Cell Biol 108:1863-1872.

Benfenati F, Valtorta F, Chieregatti E, Greengard P (1992a) Interaction of free and synaptic vesicle-bound synapsin I with F-actin. Neuron 8:377-386.

Benfenati F, Valtorta F, Rubenstein JL, Gorelick FS, Greengard P, Czernik AJ (1992b) Synaptic vesicle-associated $\mathrm{Ca}^{2+} /$ calmodulin-dependent protein kinase II is a binding protein for synapsin I. Nature 359:417-420.

Benfenati F, Valtorta F, Neyroz P, Greengard P (1993a) Binding of synapsin I to synaptic vesicles: clues from the study of its interactions with liposomes. J Liposome Res 3:599-609.

Benfenati F, Valtorta F, Rossi MC, Onofri F, Sihra T, Greengard P (1993b) Interactions of synapsin I with phospholipids: possible role in synaptic vesicle clustering and in the maintenance of bilayer structures. J Cell Biol 123:1845-1855.

Bernstein BW, DeWit M, Bamburg JR (1998) Actin disassembles reversibly during electrically induced recycling of synaptic vesicles in cultured neurons. Brain Res Mol Brain Res 53:236-251.

Bloom O, Evergren E, Tomilin N, Kjaerulff O, Low P, Brodin L, Pieribone VA, Greengard P, Shupliakov A (2003) Colocalization of synapsin and actin during synaptic vesicle recycling. J Cell Biol 161:737-747.

Bommert K, Charlton MP, DeBello WM, Chin GJ, Betz H, Augustine GJ (1993) Inhibition of neurotransmitter release by C2-domain peptides implicates synaptotagmin in exocytosis. Nature 363:163-165.

Brautigam CA, Chelliah Y, Deisenhofer J (2004) Tetramerization and ATP binding by a protein comprising the $\mathrm{A}, \mathrm{B}$ and $\mathrm{C}$ domains of rat synapsin $\mathrm{I}$. J Biol Chem 279:11948-11956.

Burns ME, Sasaki T, Takai Y, Augustine GJ (1998) Rabphilin-3A: a multifunctional regulator of synaptic vesicle traffic. J Gen Physiol 111:243-255.

Ceccaldi PE, Grohovaz F, Benfenati F, Chieregatti E, Greengard P, Valtorta F (1995) Dephosphorylated synapsin I anchors synaptic vesicles to actin cytoskeleton: an analysis by videomicroscopy. J Cell Biol 128:905-912.

Chamberlain LH, Roth D, Morgan A, Burgoyne RD (1995) Distinct effects of $\alpha$-SNAP, 14-3-3 proteins and calmodulin on priming and triggering of regulated exocytosis. J Cell Biol 130:1063-1070.

Cheetham JJ, Hilfiker S, Benfenati F, Weber T, Greengard P, Czernik AJ (2001) Identification of synapsin I peptides that insert into lipid membranes. Biochem J 354:57-66.

Chen YA, Duvvuri V, Schulman H, Scheller RH (1999) Calmodulin and protein kinase $\mathrm{C}$ increase $\mathrm{Ca}^{2+}$-stimulated secretion by modulating membrane-attached exocytic machinery. J Biol Chem 274:26469-26476.

Chi P, Greengard P, Ryan TA (2001) Synapsin dispersion and reclustering during synaptic activity. Nat Neurosci 4:1187-1193.

Chi P, Greengard P, Ryan TA (2003) Synaptic vesicle mobilization is regulated by distinct synapsin I phosphorylation pathways at different frequencies. Neuron 38:69-78.

Chilcote TJ, Siow YL, Schaeffer E, Greengard P, Thiel G (1994) Synapsin IIa bundles actin filaments. J Neurochem 63:1568-1571.

Cole JC, Villa BR, Wilkinson RS (2000) Disruption of actin impedes transmitter release in snake motor terminals. J Physiol (Lond) 525:579-586.

Czernik AJ, Pang DT, Greengard P (1987) Amino acid sequences surrounding the cAMP-dependent and calcium/calmodulin-dependent phosphorylation sites in rat and bovine synapsin I. Proc Natl Acad Sci USA 84:7518-7522.

DeBello WM, O'Connor V, Dresbach T, Whiteheart SW, Wang SS, Schweizer FE, Betz H, Rothman JE, Augustine GJ (1995) SNAP-mediated proteinprotein interactions essential for neurotransmitter release. Nature 373:626-630.

De Camilli P, Benfenati F, Valtorta F, Greengard P (1990) The synapsins. Annu Rev Cell Biol 6:433-460.

Doussau F, Augustine GJ (2000) The actin cytoskeleton and neurotransmitter release: an overview. Biochimie 82:353-363.

Esser L, Wang C, Hosaka M, Smagula CS, Südhof TC, Deisenhofer J (1998) Synapsin I is structurally similar to ATP-utilizing enzymes. EMBO J 17:977-984.

Feng J, Chi P, Blanpied TA, Xu Y, Magarinos AM, Ferreira A, Takahashi RH, Kao HT, McEwen BS, Ryan TA, Augustine GJ, Greengard P (2002) Reg- ulation of neurotransmitter release by synapsin III. J Neurosci 22:4372-4380.

Fesce R, Benfenati F, Greengard P, Valtorta F (1992) Effects of the neuronal phosphoprotein synapsin I on actin polymerization. J Biol Chem 267:11289-11299.

Gitler D, Xu Y, Kao HT, Lin D, Lim S, Feng J, Greengard P, Augustine GJ (2004a) Molecular determinants of synapsin targeting to presynaptic terminals. J Neurosci 24:3711-3720.

Gitler D, Takagishi Y, Feng J, Ren Y, Rodriguiz RM, Wetsel WC, Greengard P, Augustine GJ (2004b) Different presynaptic roles of synapsins at excitatory and inhibitory synapses. J Neurosci 24:11368-11380.

Greengard P, Valtorta F, Czernik AJ, Benfenati F (1993) Synaptic vesicle phosphoproteins and regulation of synaptic function. Science 259:780-785.

Hayes NVL, Bennett AF, Baines AJ (1991) Selective $\mathrm{Ca}^{2+}$-dependent interaction of calmodulin with the head domain of synapsin I. Biochem J 275:93-97.

Hemmings HC, Girault J-A, Williams KR, LoPresti MB, Greengard P (1989) ARPP-21, a cyclic AMP-regulated phosphoprotein $(\mathrm{Mr}=21,000)$ enriched in dopamine-innervated brain regions. J Biol Chem 264:7726-7733.

Hess SD, Doroshenko PA, Augustine GJ (1993) A functional role for GTPbinding proteins in synaptic vesicle cycling. Science 259:1169-1172.

Hilfiker S, Schweizer FE, Kao HT, Czernik AJ, Greengard P, Augustine GJ (1998) Two sites of action for synapsin domain $\mathrm{E}$ in regulating neurotransmitter release. Nat Neurosci 1:29-35.

Hilfiker S, Pieribone VA, Czernik AJ, Kao HT, Augustine GJ, Greengard P (1999) Synapsins as regulators of neurotransmitter release. Philos Trans R Soc Lond B Biol Sci 354:269-279.

Hilfiker S, Czernik AJ, Greengard P, Augustine GJ (2001) Tonically active protein kinase A regulates neurotransmitter release at the squid giant synapse. J Physiol (Lond) 531:141-146.

Hosaka M, Südhof TC (1998a) Synapsins I and II are ATP-binding proteins with differential $\mathrm{Ca}^{2+}$ regulation. J Biol Chem 273:1425-1429.

Hosaka M, Südhof TC (1998b) Synapsin III, a novel synapsin with an unusual regulation by $\mathrm{Ca}^{2+}$. J Biol Chem 273:13371-13374.

Hosaka M, Hammer RE, Südhof TC (1999) A phospho-switch controls the dynamic association of synapsins with synaptic vesicles. Neuron 24:377-387.

Humeau Y, Doussau F, Vitiello F, Greengard P, Benfenati F, Poulain B (2001) Synapsin controls both reserve and releasable synaptic vesicle pools during neuronal activity and short-term plasticity in Aplysia. J Neurosci 21:4195-4206.

Hunt JM, Bommert K, Charlton MP, Kistner A, Habermann E, Augustine GJ, Betz H (1994) A postdocking role for synaptobrevin in synaptic vesicle fusion. Neuron 12:1269-1279.

Hurley SL, Brown DL, Cheetham JJ (2004) Cytoskeletal interactions of synapsin I in non-neuronal cells. Biochem Biophys Res Commun 317:16-23.

Huttner WB, Greengard P (1979) Multiple phosphorylation sites in protein I and their differential regulation by cyclic AMP and calcium. Proc Natl Acad Sci USA 76:5402-5406.

Huttner WB, Schiebler W, Greengard P, De Camilli P (1983) Synapsin I (Protein I), a nerve terminal-specific phosphoprotein. III. Its association with synaptic vesicles studied in a highly purified synaptic vesicle preparation. J Cell Biol 96:1374-1388.

Job C, Lagnado L (1998) Calcium and protein kinase C regulate the actin cytoskeleton in the synaptic terminal of retinal bipolar cells. J Cell Biol 143:1661-1672.

Kaczmarek LK, Jennings KR, Strumwasser F, Nairn AC, Walter U, Wilson FD, Greengard P (1980) Microinjection of catalytic subunit of cyclic AMPdependent protein kinase enhances calcium action potentials of bag cell neurons in cell culture. Proc Natl Acad Sci USA 77:7487-7491.

Kao HT, Porton B, Czernik AJ, Feng J, Yiu G, Haring M, Benfenati F, Greengard P (1998) A third member of the synapsin gene family. Proc Natl Acad Sci USA 95:4667-4672.

Kao HT, Porton B, Hilfiker S, Stefani G, Pieribone VA, DeSalle R, Greengard $\mathrm{P}$ (1999) Molecular evolution of the synapsin gene family. J Exp Zool 285:360-377.

Klagges BR, Heimbeck G, Godenschwege TA, Hofbauer A, Pflugfelder GO, Reifegerste R, Reisch D, Schaupp M, Buchner S, Buchner E (1996) Invertebrate synapsins: a single gene codes for several isoforms in Drosophila. J Neurosci 16:3154-3165. 
Kuromi H, Kidokoro Y (1998) Two distinct pools of synaptic vesicles in single presynaptic boutons in temperature-sensitive drosophila mutant, shibire. Neuron 20:917-925.

Laemmli UK (1970) Cleavage of structural proteins during the assembly of the head of bacteriophage T4. Nature 227:680-685.

Li L, Chin LS, Shupliakov O, Brodin L, Sihra TS, Hvalby O, Jensen V, Zheng D, McNamara JO, Greengard P (1995) Impairment of synaptic vesicle clustering and of synaptic transmission, and increased seizure propensity, in synapsin I-deficient mice. Proc Natl Acad Sci USA 92:9235-9239.

Morales M, Colicos MA, Goda Y (2000) Actin-dependent regulation of neurotransmitter release at central synapses. Neuron 27:539-550.

Nicol S, Rahman D, Baines AJ (1997) $\mathrm{Ca}^{2+}$-dependent interaction with calmodulin is conserved in the synapsin family: identification of a highaffinity site. Biochemistry 36:11487-11495.

O’Connor V, Heuss C, DeBello WM, Dresbach T, Charlton MP, Hunt JH, Pellegrini LL, Hodel A, Burger MM, Betz H, Augustine GJ, Schaefer T (1997) Disruption of syntaxin-mediated protein interactions blocks neurotransmitter secretion. Proc Natl Acad Sci USA 94:12186-12191.

Parsons TD, Coorssen JR, Horstmann H, Almers W (1995) Docked granules, the exocytotic burst, and the need for ATP hydrolysis in endocrine cells. Neuron 15:1085-1096.

Petrucci T, Morrow JS (1987) Synapsin I: an actin-bundling protein under phosphorylation control. J Cell Biol 105:1355-1363.

Picciotto MR, Cohn JA, Bertuzzi G, Greengard P, Nairn AC (1992) Phosphorylation of the cystic fibrosis transmembrane conductance regulator. J Biol Chem 267:12742-12752.

Picciotto MR, Czernik AJ, Nairn AC (1993) Calcium/calmodulindependent protein kinase I. CDNA cloning and identification of autophosphorylation site. J Biol Chem 268:26512-26521.

Pieribone VA, Shupliakov O, Brodin L, Hilfiker-Rothenfluh S, Czernik AJ, Greengard P (1995) Distinct pools of synaptic vesicles in neurotransmitter release. Nature 375:493-497.

Quetglas S, Iborra C, Sasakawa N, De Haro L, Kumakura K, Sato K, Leveque C, Seagar M (2002) Calmodulin and lipid binding to synaptobrevin regulates calcium-dependent exocytosis. EMBO J 21:3970-3979.

Rosahl TW, Geppert M, Spillane D, Herz J, Hammer RE, Malenka RC, Südhof TC (1993) Short-term synaptic plasticity is altered in mice lacking synapsin I. Cell 75:661-670.

Rosahl TW, Spillane D, Missler M, Herz J, Seling OK, Wolff JR, Hammer RE, Malenka RC, Südhof TC (1995) Essential functions of synapsins I and II in synaptic vesicle regulation. Nature 375:488-493.

Sanchez ME, Nuno CM, Buchanan J, Augustine GJ (1990) Contractions of the squid stellate ganglion. J Exp Biol 152:269-387.

Sankaranarayanan S, Atluri PP, Ryan TA (2003) Actin has a molecular scaffolding, not propulsive, role in presynaptic function. Nat Neurosci 6:127-134.

Sakaba T, Neher E (2003) Involvement of actin polymerization in vesicle recruitment at the calyx of Held synapse. J Neurosci 23:837-846.

Schiebler W, Jahn R, Doucet JP, Rothlein J, Greengard P (1986) Character- ization of synapsin I binding to small synaptic vesicles. J Biol Chem 261:8383-8390.

Schikorski T, Stevens CF (1997) Quantitative ultrastructural analysis of hippocampal excitatory synapses. J Neurosci 17:5858-5867.

Schweizer FE, Dresbach T, DeBello WM, O’Connor V, Augustine GJ, Betz H (1998) Regulation of neurotransmitter release kinetics by NSF. Science 279:1203-1206.

Shupliakov O, Bloom O, Gustafsson JS, Kjaerulff O, Löw P, Tomilin N, Pieribone VA, Greengard P, Brodin L (2002) Impaired recycling of synaptic vesicles after acute perturbation of the presynaptic actin cytoskeleton. Proc Natl Acad Sci USA 99:14476-14481.

Sihra TS, Wang JK, Gorelick FS, Greengard P (1989) Translocation of synapsin I in response to depolarization of isolated nerve terminals. Proc Natl Acad Sci USA 86:8108-8112.

Südhof TC, Czernik AJ, Kao HT, Takei K, Johnston PA, Horiuchi A, Kanazir SD, Wagner MA, Perin MS, De Camilli P, Greengard P (1989) Synapsins: mosaics of shared and individual domains in a family of synaptic vesicle phosphoproteins. Science 245:1474-1480.

Swandulla D, Hans M, Zipser K, Augustine GJ (1991) Role of residual calcium in synaptic depression and posttetanic potentiation: fast and slow calcium signaling in nerve terminals. Neuron 7:915-926.

Takei Y, Harada A, Takeda S, Kobayashi K, Terada S, Noda T, Takahashi T, Hirokawa N (1995) Synapsin I deficiency results in the structural change in the presynaptic terminals in the murine nervous system. J Cell Biol 131:1789-1800.

Tanaka T, Kato H, Nishioka T, Oda J (1992) Mutational and proteolytic studies on a flexible loop in glutathione synthetase from Escherichia coli B: the loop and arginine 233 are critical for the catalytic reaction. Biochemistry 31:2259-2265.

Thiel G, Südhof TC, Greengard P (1990) Synapsin II. Mapping of a domain in the $\mathrm{NH} 2$-terminal region which binds to small synaptic vesicles. J Biol Chem 265:16527-16533.

Torri-Tarelli F, Bossi M, Fesce R, Greengard P, Valtorta F (1992) Synapsin I partially dissociates from synaptic vesicles during exocytosis induced by electrical stimulation. Neuron 9:1143-1153.

Valtorta F, Greengard P, Fesce R, Chieregatti E, Benfenati F (1992) Effects of the neuronal phosphoprotein synapsin I on actin polymerization. J Biol Chem 267:11281-11288.

Walsh DA, Glass DB (1991) Utilization of the inhibitor protein of adenosine cyclic monophosphate-dependent protein kinase, and peptides derived from it, as tools to study adenosine cyclic monophosphate-mediated cellular processes. Methods Enzymol 201:304-316.

Walsh DA, Ashby CD, Gonzalez C, Calkins D, Fischer EH, Krebs EG (1971) Purification and characterization of a protein inhibitor of adenosine $3^{4}, 5^{4}$ monophosphate-dependent protein kinases. J Biol Chem 246:1977-1985.

Wang XH, Zheng JQ, Poo MM (1996) Effect of cytochalasin treatment in short-term synaptic plasticity at developing neuromuscular junctions in frogs. J Physiol (Lond) 491:187-195. 